\title{
Authors'reply: Concern regarding the alleged spread of hypervirulent lymphogranuloma venereum Chlamydia trachomatis strain in Europe
}

F Petrovay ${ }^{1}$, E Balla ${ }^{1}$, T Erdősi 2

1. Department of Bacteriology II., National Centre for Epidemiology, Budapest, Hungary

2. Department of Phage and Molecular Typing, National Centre for Epidemiology, Budapest, Hungary

Correspondence: Eszter Balla (drballa.eszter@gmail.com)

Citation style for this article:

Petrovay F, Balla E, Erdősi T. Authors'reply: Concern regarding the alleged spread of hypervirulent lymphogranuloma venereum Chlamydia trachomatis strain in Europe. Euro Surveill. 2017;22(15):pii=30512. DOI: http://dx.doi.org/10.2807/1560-7917.ES.2017.22.15.30512

Article submitted on 22 March 2017 / accepted on 12 April 2017 / published on 13 April 2017

To the editor: A recent letter by Chlamydia researchers [1] reflected on our article [2], raising a question about a potential misclassification of the published Hungarian LGV genotypes that we characterised as ' $\mathrm{L} 2 \mathrm{C}$ '.

We agree with the authors of the letter that there is no established official nomenclature for lymphogranuloma venereum (LGV) genovariants. Moreover there are two so-called $\mathrm{L} 2 \mathrm{C}$ variants reported in the literature, based on different typing methodologies $[3,4]$. The reference that we used to characterise the strains in our report was the $\mathrm{L} 2 \mathrm{C}$ variant described by Somboonna et al. [4]. In particular, a partial sequence of the ompA gene of this variant was employed for typing, and, as stated in the letter, 'It is important to recognise that the use of the term 'L2C genotype' in the case of the L2-D recombinant strain is a misnomer, as the ompA-genotype of this strain is an archetypal L2', this sequence proved to be identical, at least at protein level, to the L2 sequence.

This fact was clarified by the LGV Genotype Dynamics Study Group, University of Basel. Due to the confusing situation of the LGV nomenclature, we have contacted this LGV research laboratory aiming to further collaborate and subtype the DNA-samples of the reported Hungarian LGV strains. We would like to point out that the Hungarian genovariants differ from the $L 2 b$ variant spreading in western European countries, as was confirmed by comparison to different reference sequences of L2b sent by the LGV Genotype Dynamics Study Group, who suggested to describe the Hungarian isolates as 'L2' genovariants until further more detailed genomic analysis.

As we do not know yet whether they prove to be a new L2 type or not, we recommend to wait with the classification of these strains until we have the final typing results. We agree that only further investigation, such as whole genomic sequencing and phylogenetic analysis can confirm the genomic background and these techniques may reveal some misnomers of LGV genotypes reported previously in other publications.

Conflict of interest

None declared.

Authors' contributions

FP, EB and TE prepared the letter collectively.

\section{References}

1. Seth-Smith HM, Galán JC, Goldenberger D, Lewis DA, Peuchant 0 , Bébéar $C$, et al. Concern regarding the alleged spread of hypervirulent lymphogranuloma venereum Chlamydia trachomatis strain in Europe. Euro Surveill. 2017;22(15):30511. DOI: $10.2807 / 1560-7917 . E S .2017 \cdot 22.15 \cdot 30511$

2. Petrovay F, Balla E, Erdősi T. Emergence of the lymphogranuloma venereum L2C genovariant, Hungary, 2012 to 2016. Euro Surveill. 2017;22(5):30455. DOI: 10.2807/1560-7917. ES.2017.22.5.30455 PMID: 28183394

3. Somboonna N, Wan R, Ojcius DM, Pettengill MA, Joseph SJ, Chang $A$, et al. Hypervirulent Chlamydia trachomatis clinical strain is a recombinant between lymphogranuloma venereum (L(2)) and D lineages. MBio. 2011;2(3):e00045-11. DOI: 10.1128/ mBio.00045-11 PMID: 21540364

4. Stary G, Meyer T, Bangert C, Kohrgruber N, Gmeinhart B, Kirnbauer R, et al. New Chlamydia trachomatis L2 strains identified in a recent outbreak of lymphogranuloma venereum in Vienna, Austria. Sex Transm Dis. 2008;35(4):377-82. DOI: 10.1097/OLQ.ob013e31815d6df8 PMID: 18209688

\section{License and copyright}

This is an open-access article distributed under the terms of the Creative Commons Attribution (CC BY 4.0) Licence. You may share and adapt the material, but must give appropriate credit to the source, provide a link to the licence, and indicate if changes were made.

This article is copyright of the authors, 2017. 